(C) 1987 ISIJ

\title{
人工格子金属
}

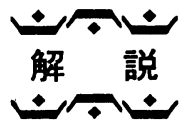

新 庄 輝 也*

\section{Artificially Structured Metallic Multilayers}

\section{Teruya SHINJO}

\section{1.はじめに}

本誌の読者の多くの方々にとつては「鉄」は安い金属 の代表的な例であり，その值段は $\mathrm{t}$ あたりで計算され るのが常識であろう。ところで，これから紹介するのは $1 \mathrm{~g}$ あたり数百万円という值段の高い鉄を用いた研究で ある. 我々の研究の推移に沿つた順序で話を進めさせて いただくとして，まずメスバウアー分光法を用いた界面 磁性の研究について説明し, ひきつづき新物質として注 目されている人工格子について解説する.

\section{2. 界 面 磁 性}

原子核が放出するガンマ線の共鳴吸収（メスバウアー 効果）を利用して物性を研究する手段がメスバウアー分 光法である. ${ }^{57} \mathrm{Fe}$ がメスバウアー効果にたいへん都合 の良い原子核であつたことが幸いし，鉄を含む物質を調 ベる手段としてメスバウアー分光法はたいへん有用であ り，したがつて読者の中にはその内容を承知しておられ る方も少なくないと思われる．紙面に制限があり，ここ ではその原理などの解説ははぶくので必要があれば参考 書などを見ていただきたい1).

界面磁性の問題としてとり上げるのは, たとえば「強 磁性金属である Feにおいて，表面（界面）層の原子も 内部と同様の磁気モーメントを持つて強磁性秩序に参加 しているかどうか」といつた点である. 表面や界面に対 する関心は近年高まつているが, 磁性の分野においても 結晶内部についての理解が進んだせいもあつて特殊な環 境である表面界面のふるまいが注目されるようになつ た. 界面磁性の実験的研究の難しさは, 磁気モーメント が界面効果で変化するとしてもせいぜい 1 ないし 2 原子 層程度にしか現れないところにある，通常のマクロな実 験手段で磁気的な界面効果を観測することは非常に困難 である.このような界面磁性の研究にメスバウアー分光 法を導入してみようというのが筆者のもくろみであり， 研究を開始してすでに約 17 年が経過した. その間の成
果のひとつが Fig. 1 のような構造の試料を作つてメス バウアー分光法を界面研究に応用する手法の開発であ $ろ^{2)}$.

メスバウアー分光法で観測の対象となる ${ }^{57} \mathrm{Fe}$ は，天 然の $\mathrm{Fe}$ の中に約 $2 \%$ 含まれている安定同位元素であ る. Fe の主成分は約 $92 \%$ を占める ${ }^{56} \mathrm{Fe}$ であるが, ${ }^{57} \mathrm{Fe}$ や ${ }^{56} \mathrm{Fe}$ をそれぞれ分離濃縮したものを購入するこ とができる. Fig. 1 はこれらの同位元素を真空蒸着法 によつて順次積層して作成したものである. 界面の研究 は三次元的な厚さを持つ試料（できれば単結晶）の界面 を対象として始めることが望ましい.この研究に用いる 試料は蒸着膜で単結晶ではないが, 蒸着 $\mathrm{Fe}$ 層の厚さが $100 \AA$ 程度あればバルクとほぼ等しい磁気的性質を示す ことが認められている. Fig. 1(A) の場合まず ${ }^{56} \mathrm{Fe}$ の $100 \AA$ の層を作り, ついで ${ }^{57} \mathrm{Fe}$ を $3.5 \AA$ 蒸着する. 更 にその表面に非磁性金属 V を蒸着し, 強磁性 Fe と非磁 性Vが接する界面を人工的に作る。 ${ }^{56} \mathrm{Fe}$ と ${ }^{57} \mathrm{Fe}$ の性質 には全く差はないので図のような構造が実現されれば $\mathrm{Fe}$ 層としては $103.5 \AA$ の厚さを持つが, メスバウアー 効果のためのプローブの ${ }^{57} \mathrm{Fe}$ は界面から深さ $3.5 \AA$, すなわち界面 2 原子層にのみ配置された試料が得られる
(A)

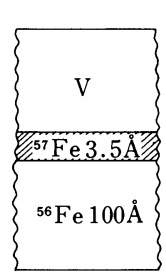

(B)

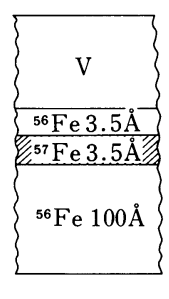

Substrate
(C)

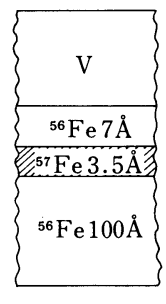

Fig. 1. Schematically illustrated cross sections of surface-selectively enriched samples for the study of interface between $\mathrm{Fe}$ and $\mathrm{V}$ by means of ${ }^{57} \mathrm{Fe}$ Mössbauer spectroscopy.

昭和 62 年 1 月 28 日受付 (Received Jan. 28, 1987) (依頼解説)

* 京都大学化学研究所教授 理博 (Institute for Chemical Research, Kyoto University, Gokasho Uji 611)

Key words : Mössbauer effect ; magnetic thin film ; vacuum evaporation; artificial superlattice ; magnetic hyperfine field ; magnetism ; superconducting materials ; laminated thin film ; ${ }^{57} \mathrm{Fe}$. 
はずである. Fig. 1(B) および $(\mathrm{C})$ のように ${ }^{57} \mathrm{Fe}$ 層の 上に更に適当な厚さの ${ }^{56} \mathrm{Fe}$ 層を蒸着すれば ${ }^{57} \mathrm{Fe}$ プ ローブ層は界面から任意の深さに配置され, 深さ方向に 層別解析を行うことができる.

Fig. 1 の試料によるメスバウアースペクトルが Fig. 2 に示されている. ${ }^{57} \mathrm{Fe}$ 層が界面から 7 ないし $10.5 \AA$ の深さ領域にある時のスペクトルはシャープな 6 本の吸 収からなり，バルクの状態と等しい（ただし強度比は 3 : 4:1:1:4:3 となつており, 磁化が面内にねている ことを示している.）3.5〜 7 の領域でも変化はわずか である。０ないし $3.5 \AA$ ，すなわち界面 2 原子層ではス ペクトルがかなり変化し，ブロードになつている。この スペクトルは, 界面層の内部磁場にはかなり分布があり, 平均値はやや減少していることを示している。したがつ て界面層の $\mathrm{Fe}$ 原子の磁気モーメントは若干減少してい るものと思われる. しかし常磁性の状態は全く存在して いない.すなわち界面第一原子層の $\mathrm{Fe}$ 原子も磁気モー メントを持つて強磁性配列している。このような実験を

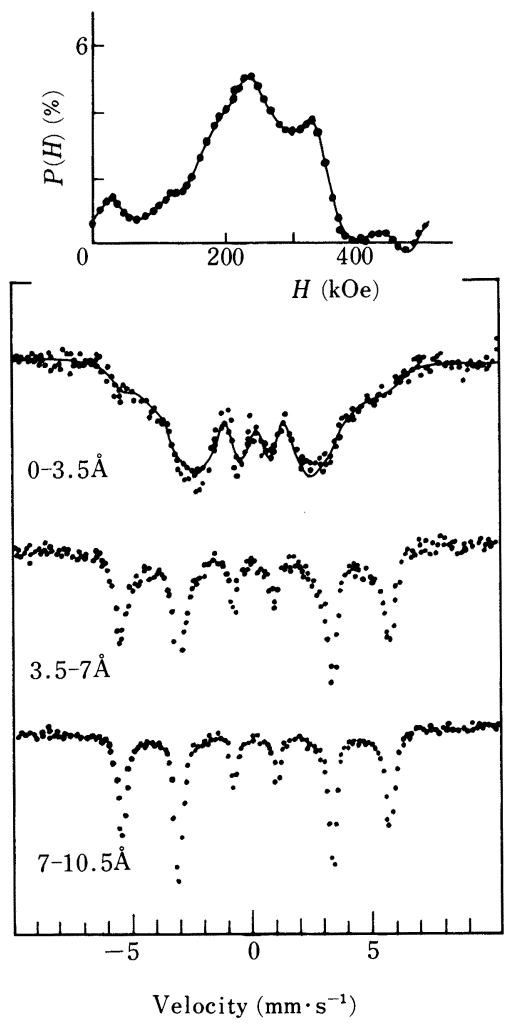

Fig. 2. ${ }^{57} \mathrm{Fe}$ Mössbauer absorption spectra at 4.2 $\mathrm{K}$ for the samples shown in Fig. 1. The distribution of the hyperfine field in the sample with the depth rang of 0 to $3.5 \AA$ is also shown in the topmost figure. $H$ and $P(H)$ are the hyperfine fields and the pyobabilities.
$\mathrm{V}$ と接する場合ばかりでなく，いろいろの界面について 行つた。 その結果, 界面 $\mathrm{Fe}$ 原子の磁気モーメントがわ ずかに減少する場合 $(\mathrm{Cu}, \mathrm{Mg}, \mathrm{Sb}$ などと接する界面 $)$ と逆にわずかに増加する場命 $\left(\mathrm{MgO}, \mathrm{MgF}_{2}\right.$ などと接す る界面）があることがわかつた3．いずれの場合も界面 層の原子は磁気モーメントを持つており，界面では磁気 モーメントが消失するという仮説 (Dead layer モデル とよばれ，1970 年頃に提案された いる.

このような界面の磁気モーメントの挙動に対して統一 的な解釈を与えるにはいたつていないが，最近の理論的 研究では真空表面の磁気モーメントは増加すると予想さ れている ${ }^{5)}$. 他方界面を被覆する物質との化学結合は磁 気モーメントを減少させると考えられる。この両者が競 合することにより，界面原子の磁気モーメントには増加 する場合と減少する場合が存在するのであろうと解釈で きる.

ところで, ${ }^{57} \mathrm{Fe}$ は購入できるとはいえ， $1 \mathrm{mg}$ あたり 約 3000 円という高価な消耗品であり， ${ }^{56} \mathrm{Fe}$ はひとけ た安いもののやはり高価である。しかもこれらをひとた び混合してしまうと分離再生は不可能で，高いものどう し混ぜたものが「ただ」の鉄になつてしまう。幸い真空 蒸着法ではごく少量の蒸発源によつて試料を生成でき る.一回あたりの消費量は $\mathrm{mg}$ 単位ですむのでこのよj な実験が可能である。 ${ }^{56} \mathrm{Fe}$ と ${ }^{57} \mathrm{Fe}$ を複合しても実用上 の性質は普通の $\mathrm{Fe}$ となんら変わらず，応用面での利用 価值にはなんのプラスもない. しかし基礎研究にとつて たいへんユニークな試料であり，試料の高価さに十分見 合う情報を与えてくれる。我々はこの手法が新しい界面 研究手段として評価できるものと自負しているが，読者 諸兄はこの研究内容をどのように評価されるであろう 加.

このような実験を通じて我々は薄膜生成の経験を積 み，オングストローム単位の膜厚制御が不可能ではない という感触を得てきた．蒸着膜の厚さを数原子層にでき るなら複数の物質の積層によつて新しい物質が作り出せ るのではないかという発想が当然浮んでくる ${ }^{6)}$. 多層膜 は界面磁性の研究にとつても興味深い対象であり, 我々 は次章に述べるような多層膜作りに向かうことになつ た。界面磁性という基礎的な研究の延長が次に紹介する ような新物質として注目される多層膜生成という発展に 結びついた。多層膜作りが可能であれば逆に Fig. 1の ような試料の構造の信頼性に強力な保証を与えることが できる. Fig. 1 の構造が試料中に本当に実現している かどうかを験証することは困難であり，その点に関して いえば我々の 10 年前の研究発表は説得力に欠けていた ことは認めざるをえない. 当時は数原子層の厚さの金属 膜がフラットな層を作つているはずがないと考えておら れる専門家が少なくなかつた。しかし多層膜作りの成功 
によつて、おそまきながら Fig. 1 の設計どおりの試料 が作られていたと信じる根拠を得ることができた。

\section{3. 人工格子の生成}

Fig. 3 は我々が多層膜の生成に用いている超高真空 蒸着装置の概要である.電子銃加熱によつて蒸着を行い, 蒸着膜の厚さは水晶発振式膜厚計によつて測定し, その 指令によつて開閉するシャッターが各層の厚さを制御す

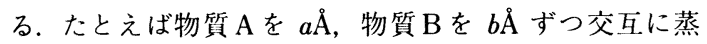
着し, 数 100 回の繰返しを行う. A と B が 3 原子層ず つ積層できたとすれば得られる構造は挿入図のようであ ろう。このような人工的周期性が作られた時, その存在 を確認するための第 1 の手段はX線回折である. 通常の $\mathrm{X}$ 線回折では結晶中に自然に存在する面間隔 $d$ が観測 の対象となり, いわゆるブラッグの式 $2 d \sin \theta=n \lambda を$ 満足する角度 $\theta$ で皮射が起こる. 人工周期構造の波長が

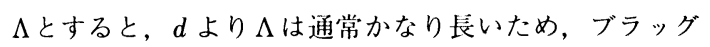
反射角は低角度となる. すなわち人工周期性が生成され た証拠を得るためには低角度領域の X線回折の測定が必 要である.

金属元素を組み合わせた多層膜生成の試みはわれわれ をはじめ日本とアメリカのいくつかのグループで最近活 発に行われているが, いろいろな組合せについての成功 例がすでに報告されている．組合せによつては人工周期 の長さを $10 \AA$ 以下にすることも可能であり, 一方を単 原子層にすることもできる. 人て周期の長さが数原子層 という短さになれば, その構造はもとの物質の格子を組

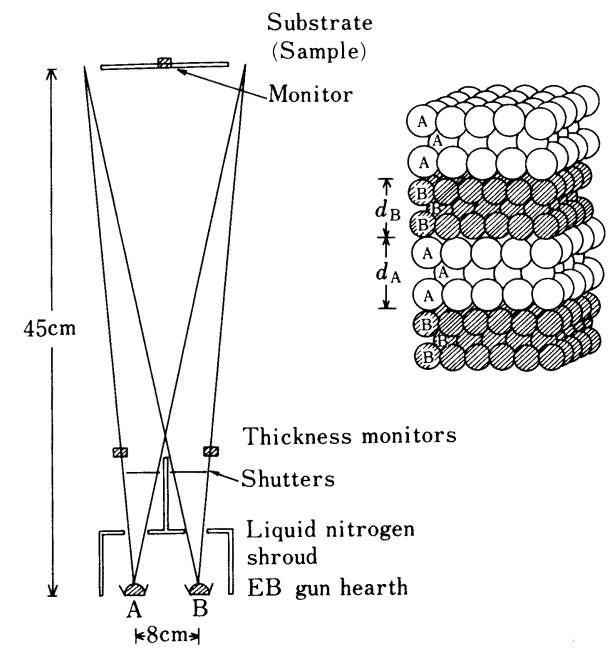

Fig. 3. The illustration of main part of vacuum deposition system for the preparation of metallic multilayers, whose structure for instance is shown in the inserted figure.
み合わせたというより全体として新しい格子が作られた と見なすべきであり，そのような多層膜を我々は人工格 子と呼んでいる7).

人工格子を構造面から大別すると，よく似た元素を組 み合わせて全体がエピタキシャルに成長する場合と, 異 質な元素の組合せによるノンエピタキシャルな場合に分 けられる. エピタキシャル人工格子では結晶構造は連続 であり, 化学組成が変調されている. 半導体の分野では 単結晶多層膜の合成が盛んであり，たとえば GaAs と $\mathrm{AlAs}$ を組み合わせた超格子がよく知られている．金属 元素によるエピタキシャル人工格子も同様のイメージで 理解することができる.

一方, 原子半径も異なり, 構造の違う物質を組み合わ せた場合はエピタキシャルな積層は不可能である。この ような場合に人工格子が生成できるかどうかについては 必ずしも楽観的な見通しが持たれていたわけではない. ところがいろいろな元素を組み合わせて試みていると非 常に多くの場合に人工格子の生成が可能であることがわ かつてきた，異質な組合せの極端な例として Fe と Mg からなる人工格子の場合をここで紹介しておく政． Fe と $\mathrm{Mg}$ は液相でさえほとんど溶け合わない組合せで $\mathrm{Fe}$ の結晶構造は bcc であるのに対し, Mg は hcp であり, 原子半径は $\mathrm{Mg}$ の方が $20 \%$ 以上大きい. しかしこの 2 種類の金属を交互に蒸着するときれいな人工周期構造が

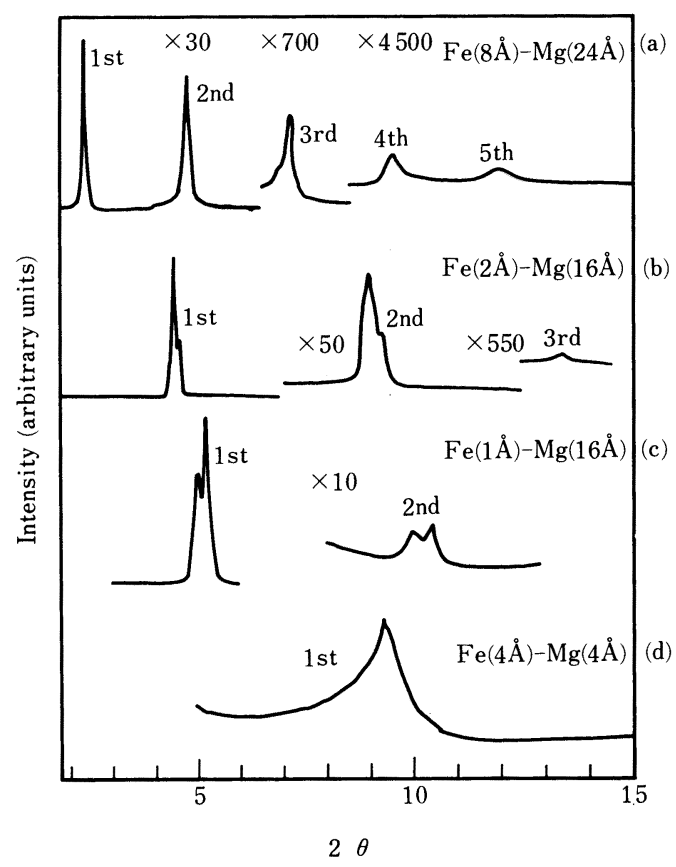

Fig. 4. Examples of X-ray diffraction pattern of $\mathrm{Fe}-\mathrm{Mg}$ superlattice in a small angle region. 


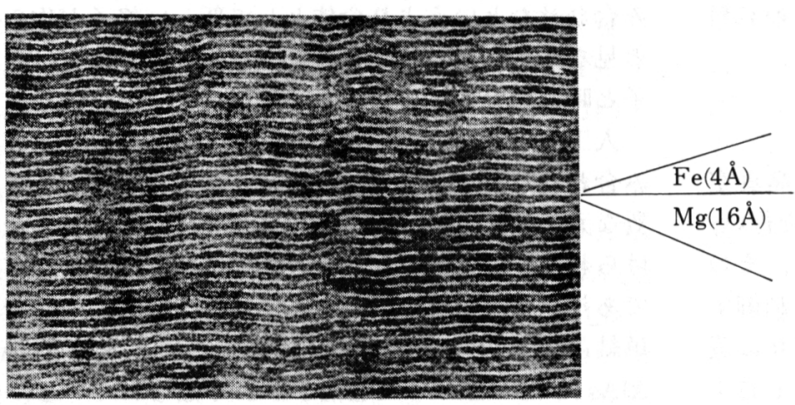

Photo. 1. Transmission electron micrograph of a cross section of an $\mathrm{Fe}-\mathrm{Mg}$ multilayer, $[\mathrm{Fe}(4 \AA)-\mathrm{Mg}(16 \AA)] \times n$.

作られることがわかつた. Fig. 4 は Fe-Mg 人工格子の $\mathrm{X}$ 線回折パターンの例である. Fe $(8 \AA)-\mathrm{Mg}(24 \AA)$ を単 位として積層した場合には高次の回折パターンも明瞭で あり，組成変調がかなり角型波に近いと見なされる. 同 じ図に示されているように $\mathrm{Fe}$ 層を単原子層にまで薄く しても周期性は成立していることが明らかである.今ま でに作成した試料中で最も短い人工周期は $\mathrm{Fe}(4 \AA)-\mathrm{Mg}$

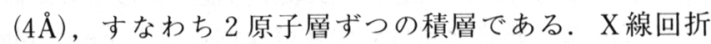
ピークの角度から試料中の組成変調周期の長さが求めら れるが,この值は膜厚計によつて設定されたデザイン值 とよく一致しており，䛊差は数Å以下である.このよう な X線回折パターンから人工周期性の成立していること には疑問の余地はないが, 更に直接的に構造を検証でき る手段は試料断面の透過電子顕微鏡観察である. Photo. 1 は $\mathrm{Fe}(4 \AA)-\mathrm{Mg}(16 \AA)$ の試料をミクロトームによつて 数 $100 \AA$ の厚さに切断したものであり, 構造は極めて均 一であることが証明されている 子層の厚みであり, 人工周期は $20 \AA$ という短さにもか かわらずかなりフラットで連続的な層状構造が見られて いる.この写真は試料を切断したためのダメージを含人 だものであり，切断前はもつと完全に近いものであつた と考えてもよかろう.

周期構造の存在を検知する手段としてはオージェ電子 分光やラザフォード後方散乱なども利用できる. しかし 界面でどのように化学組成が変化しているかミクロに調 ベることはどの手段でもかなり難しい. 一方メスバウ アー分光法や NMR が有効に利用できる場合は感度の高 い情報を得ることができる．しかしどの試料にでも応用 できるわけではなく対象はかなり制限される.

\section{4. 人工格子を用いた基礎研究}

人工格子を作成すればどのような基礎研究に応用でき るであろうか. Fe と Mg を組み合わせて周期構造に関 して極めて品質の良い試料が得られることがわかつたの で引き続き $\mathrm{Fe}-\mathrm{Mg}$ 人工格子を利用した研究を紹介す る. $\mathrm{Fe}$ は強磁性金属, $\mathrm{Mg}$ は非磁性であるが $\mathrm{Fe}$ 層の 厚さをだんだん薄くしていくとどのような変化が起こる かを調べてみた。 Fig. 5 は Fe 層の厚さが $15 \AA$ と $1 \AA$

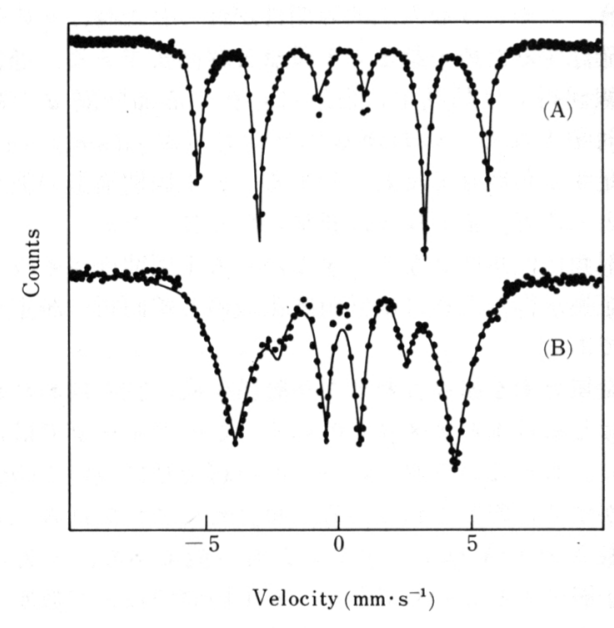

Fig. 5. ${ }^{57} \mathrm{Fe}$ Mössbauer absorption spectra at 4.2 $\mathrm{K}$ of (A) $[\mathrm{Fe}(15 \AA)-\mathrm{Mg}(30 \AA)] \times n$ and (B) $[\mathrm{Fe}(1$ $\AA)-\mathrm{Mg}(16 \AA)] \times n$.

の時のメスバウアースペクトルである. Mg 層はそれぞ れ $30 \AA$ と $16 \AA$ であり, Fe 層間の磁気相互作用は切断 されていると見なしてよい. $15 \AA$ の試料はかなりシャー プな 6 本の吸収を示し, バルクの鉄のスペクトルとほと んど差がないように見える.しかし注意深く調べると内 部磁場が減少した部分が存在していることがわかる. 図 中の曲線はバルクの内部磁場の 0.99 倍の部分が $65 \%$, 0.92 倍の部分が $35 \%$ 存在すると仮定したシミュレー ションの結果である.この 2 つの内部磁場は $\mathrm{Fe}$ 層の内 部 (バルク部分) と界面層の寄与であり, 前者はバルク, 後者は界面に対応すると考えるのが当然であろう。内部 磁場 $1 \%$ の差は誤差の範囲であり, 電子状態はほとん どバルクと差はないといえる. 一方内部磁場の減少して いる部分の体積比は $35 \%$ であり, 全体の厚さ $15 \AA$ に 0.35 をかけると $5.3 \AA$ となる. Fe 層の上下 1 原子層が この界面部分の内容であるとすれば約 $4 \AA$ のはずであ り，かなり近い值である. 界面に乱れがあれば見かけ上 少し大きな値が出るのは自然である.すなわち $\mathrm{Fe}$ 層の 
電子状態の変化は界面第一原子層でのみ顕著であると結 論できる．その界面効果は内部磁場の減少がわずか $8 \%$ であることを考えるとかなり小さいものである．先に述 ベた Fe と Vの界面に比べると界面効果つまり内部磁場 の滅少度は小さい. $\mathrm{Fe}$ と $\mathrm{Mg}$ の結合は $\mathrm{Fe}$ と Vの結合 に比べて弱いことと対忍しているのであろう。

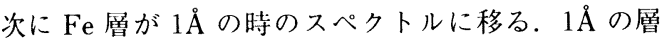
とは有限面積の単原子層の集まり（いわゆる Fractional monolayer）と考えられる。スペクトルはやはり強磁性 を示しており，常磁性状態は全く存在しない。 $15 \AA$ の スペクトルと比べるとややブロードになつているが内部 磁場の平均值を求めるとバルク值の 0.77 倍である.す なわち磁気モーメントの值は減少しているものの単原子 層でもなおかなりの大きさの磁気モーメントが存在して いることになる。さらに與味深い点は 6 本のピークの強 度比の変化である。 $15 \AA$ の試料では形状異方性が支配 的であり，磁化は面内にねているため $3: 4: 1: 1: 4: 3$

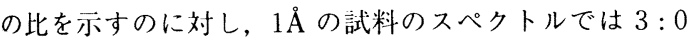
$: 1: 1: 0: 3$ に近づいており, 磁化方们が面垂直に変わ つたことを示している。このような垂值磁化は Fe 層が $2 \AA$ 以下の時にのみ見られ, 単原子層の磁性に特有の性 質であり，表面異方性が支配的になつたためと考えられ る.メスバウアースペクトルの温度変化を調べると内部 磁場の消失する温度は $2 \AA$ では約 $55 \mathrm{~K}, 1 \AA$ の試料で は約 $35 \mathrm{~K}$ である。しかしマクロな磁化測定を行うと室 温でもある程度短距離秩序が残つていることがわかる. これらの事実は単原子層の持つ磁化は熱連動によつてゆ らぎやすいという特徴にもとづいていると思われる。

上に述べたように，磁性層と非磁性層によつて構成さ れた人工格子は界面磁性を研究する試料となり，更に単 原子層磁性体の研究対象を作ることもでき, その磁気特 性が興味深いものであることが調べられつつある．とこ ろでこれらの研究の場合は人亡格子を薄膜の集合と見な しているわけで, 薄膜の磁性の研究を行つていることに なり，人工周期そのものが映する物性を対象とはして いない。しかし薄膜磁性を研究するための人工格子の有 用性は明白であり，たとえば単原子層を数 100 回含む 試料であればすべての測定が容易になる上，周期性を利 用して中性子回折を忍用することができる，さらに，構 造評価も単層の試料より人工格子の方が簡単であるなど 多くのメリットをあげることができる.

磁性の分野では人亡.周期性が直接反映する性質を研究 した例はごくわずかである．その 1 例は最近アメリカで 行われている Dy-Y 人工格子の研究である ${ }^{10)}$.この試 料は単結晶積層膜であり，人工周期と相関性のある波長 $100 \AA$ 以上の長周期磁気構造が作られていることが報告 されている。

磁性と並んで金属人工格子の基本的物性として興味深 いのは超伝導性である，超伝導の基礎的研究としてはま
ず超伝導と常伝導層を交互にサンドイッチした多層膜の 研究が行われている.アメリカでは $\mathrm{Nb}$ と常伝導物質を 組み合わせる試みがいくつか報告された，我々は超伝導 金属 $\mathrm{V}$ と単純な金属である $\mathrm{Ag}$ を積層させることに成功 した ${ }^{11)}$ 。この組合せも $\mathrm{Fe}-\mathrm{Mg}$ と同様液体状態でも溶け 合わないものであり, 今までの手法では調べられなかつ た新合金系である。このような系では V 層の超伝導性が 近接効果によつて $\mathrm{Ag}$ 層にも浸入する.したがつてコ ヒーレンスの長さが $\mathrm{Ag}$ 層よりも長ければV層どうし結 合し, 三次元的超伝導体になる. 逆にコヒーレンスの長 さが $\mathrm{Ag}$ 層より短かければ二次元的となる. 超伝導の次 元性は臨界磁場の温度变化によつて判別される.コヒー レンスの長さは温度変化するので $\mathrm{Ag}$ 層の厚さを適当に 設定すると温度によつて同じ試料の超伝導性が二次元か ら三次元に移る，いわゆる次元クロスオーバー現象が観 測できることがわかつた，超伝導層をふくむ人工格子薄 膜の性質は高橋と立木 ${ }^{12)}$ によつて理論的に考察され， いろいろな場合について臨界磁場の温度変化の予測が行 われている.したがつて実験結果と理論的予測を比較し, 定量的な議論を行うことができる.

このように人工格子は超伝導性に関する基礎的研究の対 象として非常に興味深いものである.

\section{5. 新物質としての人工格子}

前章で紹介したように，人工格子を試料とした基礎研 究については新しい成果が生み出されている. 構造をオ ングストローム単位で制御するメリットを生かし, 理論 的な考察と実験を対比させて行く新しい物性研究の境地 がひらかれつつある。また新物質開発について極めて有 望であることが既に明らかである。ここに紹介した $\mathrm{Fe}$ と $\mathrm{Mg}$ あるいは Vと $\mathrm{Ag}$ のように液相でも混合できなか つた金属どうしをミクロに複合した新しい合金は状態図 には存在しない新物質であり，熱力学的には非平衡状態 にある．蒸着法という新しい物質作りの手法を利用する ことにより我々の作りうる物質の種類は非常に広くなつ た．蒸着法の他，超急冷法，イオン注入法，レーザー照 射などの方法が物質作りに利用され始めており，これら もやはり非平衡状態の物質を作り出す特徵がある. 我々 の蒸着方法は超高真空中で行つているところにひとつの 特徴があるが，超高真空といつた特殊な技術を物質作り に利用できるようになつたのはかなり最近である．超高 真空のみならず, 超高圧, 超高温あるいは無重力など, ひと昔前は特定の分野の尃門家だけが使える，いわゆる 極端条件が物質合成と結びつけられるようになつてきた ことを最近の進歩にあげることができる.

そのような新しい物質合成のもうひとつの特徵は「金 がかかる」ということにある. 我々の人工格子生成用の 超高真空蒸着装置がざつと 1 式 5 千万円かかるとする. 1 年間に 50 個の試料が生成できるとし， 5 年間使用し 


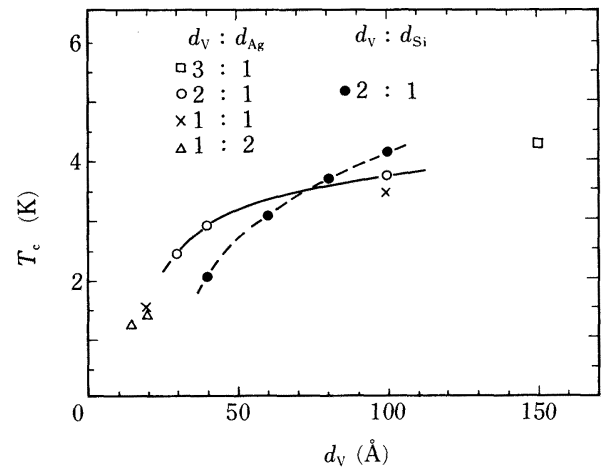

Fig. 6. Dependence of superconducting transition temperature on $\mathrm{V}$ layer thicknesses in $\mathrm{V}-\mathrm{Ag}$ and $\mathrm{V}$-Si multilayers.

たとして合計わずか 250 個である. 試料ひとつあたり の装置代の原価だけで 20 万円かかつていることにな り，まことに高くついている. しかも重量でいえば得ら れる試料 1 個あたり数 $\mathrm{mg}$ であり, 非常に高価な合金を 作り出している計算になる。基礎研究の対象としてはた いへん興味深いとはいうものの応用面での価值はまだ末 知数の域を出て㧍らず今後に期待せざるをえない，金属 人工格子がどのような面で実用と結びっく可能性がある か，現段階で予想できることを若干記してみよう。

磁性材料としての研究は近年非晶質薄膜について行わ れてきたものとよく似た方向にあり，記憶材料やへッド 材料を目標としている。構造をミクロに制御することに よつて非晶質薄膜より特性を上げることが期待されてい る. 最近 $\mathrm{Tb}-\mathrm{Fe}$ 人工格子が垂直磁化を示し, 光磁気材 料として有望であることが報告されている ${ }^{13)}$.

超伝導材料としては高い $T_{c}$ を持つ新物質の発見に期 待がかけられているが今のところ成功していない，既に 知られている超伝導金属をべースに多層化しても $T_{c}$ は 低下してしまう. Fig. 6 は V-Ag と V-Si の例であり, $\mathrm{V}$ を薄くすると $T_{c}$ は低下することを示している．Nb 系でもやはり同様の結果が得られている。人工格子は今 までになかつた新物質を作り出す手段である以上，非超 伝導物質どうしを組み合わせた未発見の超伝導物質系を 是非見つけ出したいものである.

人工格子はひずみを界面層に含んだ物質であるため異 常な弾性的性質を持つことが予想され, 実際異常な弾性 率の観測を報告している例もあるが内容の信頼性は十分 でない．いずれにしろ試料の形状は薄膜であり弾性率を 実用と結びつけるのは難しそうである.

もともと多層膜作りにもつとも古くから取り組んでき たのはX線光学の分野であり, 人工的に周期を作り, 天
然の結晶では得られない波長の干涉用格子を作る試みが なされてきた。この分野での多層膜作りはしばらく中だ るみ的停滞期にあつたようであるが，薄膜作りの技術の 進歩と放射光によつて強力な X 線が得られることが刺激 となつて再び研究が活発になつている。この分野では実 用化もある程度進んでいるようで人工衛星に多層膜を搭 載し, 宇宙X線を集光して観測する計画が実施されると 聞いている.

人エ格子の試料のコストが 1 つあたり数 10 万円かか るのでは高価すぎて特殊な用途以外には実用化は難しそ うである。しかしひとたび作るべきターゲットが決まれ ば生成の能率化をはかつてある程度コストは下げること ができよう。いずれにしてもコストの高い素材であるこ とには違いないがそれを上回る価值のある特性を持つ人 工格子が作り出されれば当然実用化が検討されよう．鉄 を成分とする人工格子に思いがけない応用面の価值が発 見されれば，鉄がミリグラムあたり何万円という新素材 の主役となつて面目を一新するかもしれない，我々の基 礎研究が刺激となって，人工格子のような新物質の応用 面を開発する研究が推進されればたいへん喜ばしいこと である.

\section{文献}

1）たとえば，新庄輝也: 実験物理学講座（伊達宗行編），24 (1980), p. 404 [共立出版]

2) $N$. Hosoito, $K$. KaWaguchi, $T$. Shinjo, $T$. TAKada and $Y$. ENDOH: J. Phys. Soc. Jpn., 53 (1984), p. 2659

3 ) S. Hine, T. SHinjo, and T. TaKada: J. Phys. Soc. Jpn., 47 (1979), p. 767

4 ) L. N. Lieberwann, D. R. Fredkin and H. B. Shore: Phys. Rev. Letters, 22 (1969), p. 539, L. N. LieberwanN, J. Clinton, D. M. Edwards and J. Mathon: Phys. Rev. Letters, 25 (1970), p. 232

5 ) S. Ohnishi, $A . J$. Freeman and M. Weinert: Phys. Rev., B28 (1983), p. 6741

6 ) 新庄輝也: 科学, 52 (1982), p. 683 [岩波書店]

7 ）金属人工格子の解説としては, Metallic Superlattices, ed. by $T$. SHINJO and T. TAKADA (1987) [Elsevier Science Publishers]

8 ) $T$. Shinjo, $N$. Hosoito, $K$. Kawaguchi, $N$. Nakayama, $T$. TAKADA and Y. ENDOH: J. Magn. \& Magn. Mater. 54-57 (1986), p. $737, K$, Kawaguchi, $R$. Yamamoto, $N$. Hosolto, T. Shinjo and T. TaKada: J. Phys. Soc. Jpn., 55 (1986), p. 2375

9 ) 撮影は石崎明美氏（キャノン中研）による.

10) M. B. Salomon, S. Sinha, J. J. Rhyne, J. E. Cunningham R. W. Erwin, J. Borchers and C. P. Flynn: Phys. Rev., Letters, 56 (1986), p. 259

11) $K$. Kanoda, $H$. Mazaki, $T$. Yamada, $N$, Hosolto and T. ShinJo: Phys. Rev., 33 (1986), p. 2052

12）高橋三郎，立木 昌: 固体物理， 21 (1986), p. 589

13) N. Sato: J. Appl. Phys., 59 (1986), p. 2514 